medRxiv preprint doi: https://doi.org/10.1101/2021.01.27.21249186; this version posted January 29, 2021. The copyright holder for this preprint (which was not certified by peer review) is the author/funder, who has granted medRxiv a license to display the preprint in perpetuity.

It is made available under a CC-BY 4.0 International license .

\title{
SARS-CoV-2 infection in Ivory Coast: a serosurveillance survey among gold mine workers
}

Jean Marie Milleliri ${ }^{1}$, Daouda Coulibaly ${ }^{2}$, Blaise Nyobe ${ }^{3}$, Jean-Loup Rey ${ }^{1}$, Franck Lamontagne ${ }^{1}$, Laurent Hocqueloux ${ }^{4}$, Susanna Giaché ${ }^{4}$, Antoine Valery ${ }^{5}$, Thierry Prazuck ${ }^{4} *$

$1:$ Groupe d'intervention en sante publique et epidemiologie, Marseille, France, 2: Institut National de sante publique, Abidjan, Cote d'Ivoire ; 3 : Medicis, Urgences, Abidjan, Cote d'Ivoire, 4 : Maladies infectieuses et tropicales, Centre Hospitalier Regional d'Orleans, France ; 5: Departement d'information medicale, Centre Hospitalier Regional d'Orleans, France

*: Corresponding author: Thierry Prazuck, Centre Hospitalier Regional d'Orleans, 14 avenue de l'hopital, 45067 Orleans, Cedex 2, France . thierry.prazuck@chr-orleans.fr, phone: 00(33) 238229593

Key words : Sars-Cov2 ; epidemiology, Africa, Ivory Coast; prevalence

Abstract: 189 words; manuscript: 2229 words

2 tables

Background: Eight months after the detection of the first COVID-19 case in Africa, 1,262,476 cases have been reported in African countries compared to 72 million worldwide. The real burden of SARS-CoV-2 infection in West Africa is not clearly defined. The aim of the study was to evaluate the seroprevalence of SARS-CoV-2 in half of the 3,380 workers of several mining companies operating in two mines in the Ivory Coast and having its headquarters in the economic capital Abidjan.

Methods: From 15th July to 13th October 2020, a voluntary serological test campaign was performed in the 3 sites where the companies operate: two mines, and the headquarters in Abidjan.We performed a COVID-PRESTO rapid test for the detection of IgG and IgM on capillary blood. A multivariate analysis was performed to identify independent sociodemographic characteristics associated with a higher SARS-CoV-2 seroprevalence rate.

Results: A total of 1,687 subjects were tested. $91 \%$ were male $(n=1,536)$ and mean age was 37 years old. The overall crude seroprevalence rate was $25.1 \%(\mathrm{n}=422)$, but differing significantly between different sites, rising from $13.6 \%(11.2 \%-16.1 \%)$ in mine A to $34.4 \%(31.1 \%-37.7 \%)$ in mine B and $34.7 \%$ (26.2\%-43.2\%) in Abidjan. Non-resident workers in mines had a significantly lower prevalence rate than those living full-time in mines. 
44 Seroprevalence was $26.5 \%$ in natives of the Ivory Coast, while people 45 coming from countries other than Africa were less likely to be SARS-CoV-2 46 seropositive. Among the 422 positive subjects, 74 reported mild symptoms 47 in the three previous months and one was hospitalized for a severe COVID4819 infection.

49 Conclusion: The prevalence of SARS-CoV-2 infection among mine workers 50 in Ivory Coast is high. The low morbidity observed has probably led to an 51 underestimation of the burden of this infection in West Africa. The high 52 prevalence reported in subjects living in Abidjan, who have not any close 53 contact with mine workers, may be indicative of the real seroprevalence in 54 the Ivory Coast capital.

55

56

57 
medRxiv preprint doi: https://doi.org/10.1101/2021.01.27.21249186; this version posted January 29, 2021. The copyright holder for this preprint (which was not certified by peer review) is the author/funder, who has granted medRxiv a license to display the preprint in perpetuity.

It is made available under a CC-BY 4.0 International license .

72 CoronaVirus Disease 2019 (COVID-19) represents an unprecedented

73 international public health challenge responsible for significant morbidity

74 and mortality. In March 2020, the World Health Organization (WHO)

75 officially declared the COVID-19 pandemic. As of 17th December 2020, the

76 Severe Acute Respiratory Syndrome CoronaVirus 2 (SARS-CoV-2) caused

77 1,637,000 deaths out of more than 72 million cases reported worldwide.

78 Unfortunately these numbers continue to increase every day ${ }^{1}$.

79 Officially, according to the latest October $21^{\text {st }} 2020$ WHO report, COVID-19

80 cases in Africa were 1,262,476 and COVID-19 related deaths were 28,601,

81 with no significant change in incidence over weeks $(29,919$ new confirmed

82 cases and 474 new deaths from 46 countries, compared to 30,145 cases and

83747 deaths in the previous week) ${ }^{2}$.

84 Considering the daily increase in the number of COVID-19 cases all around

85 the world, it appears that Africa is controlling the epidemic spread better

86 than Europe, United States or South America. Catastrophic scenarios about

87 potentially devastating effect of COVID-19 in Africa have fortunately not yet

occurred. The reasons are multiple and not always clearly established ${ }^{3}$.

89 Some authors argue that this epidemic reached Africa a few weeks after

90 Europe and African leaders adopted preventive measures thanks to

91 acquired knowledge of what was happening in Europe, having probably

92 learned important lessons from previous major outbreaks, like 2014 Ebola 
medRxiv preprint doi: https://doi.org/10.1101/2021.01.27.21249186; this version posted January 29, 2021. The copyright holder for this preprint (which was not certified by peer review) is the author/funder, who has granted medRxiv a license to display the preprint in perpetuity.

It is made available under a CC-BY 4.0 International license.

93 virus disease in West Africa. In addition, many parts of Africa are still

94 isolated and not linked to significant tourism and international business

95 related traffic. However, according to recent data, SARS-CoV-2 serological

96 positivity in South Africa appears to be so high that it approaches the herd

97 immunity threshold (i.e. more than 60\%) (Jonny Myers, Maverick Citizen,

98 Open Edition, 7 oct 2020) ${ }^{4}$. Did SARS-CoV2 infection largely and silently

99 spread in Africa, or did factors such as environment, younger population,

100 climate and policies limit the penetration of the virus in most African

$101 \quad$ countries?

102 Since March 2020, Ivory Coast, Mali and Burkina Faso have faced the SARS-

103 CoV-2 outbreak almost simultaneously. In this report, we present the

104 results of a COVID-19 serological testing campaign conducted in Ivory Coast

105 among employees of a gold mining company using a reliable rapid Point-of-

106 Care (POC) antibody test.

107

108 Background

109 Several mining companies operate in West Africa. Occupational Health

110 department is in charge of mine workers as well as administrative staff.

111 Mines are mainly located in rural areas of the country, between $200 \mathrm{~km}$ and

$112500 \mathrm{~km}$ far from the economic capital of the country (Abidjan) where these

113 companies' headquarters are located. Three-thousand three hundred and 
medRxiv preprint doi: https://doi.org/10.1101/2021.01.27.21249186; this version posted January 29, 2021. The copyright holder for this preprint (which was not certified by peer review) is the author/funder, who has granted medRxiv a license to display the preprint in perpetuity.

It is made available under a CC-BY 4.0 International license .

114 eighty people are currently working in these sites, including the Abidjan

115 headquarters. Of these 3,380 workers, 1,360 are direct employees and

1162,020 are subcontractor's employees of different companies. Direct

117 employees working in the mines live on site in a rather confined place,

118 while the subcontractor's employees come back home in their

119 villages/towns every day. Administrative staff and other workers located in

120 Abidjan headquarters are mainly exposed to COVID-19 in their daily

121 activities in contact with the Ivorian urban population of Abidjan. The

122 objective of this testing campaign was to sensitize and protect employees

123 and their families, particularly when a recent SARS-CoV-2 infection was

124 diagnosed.

125

126 Subjects and methods

127 The serological screening based on voluntary testing was conducted in the

128 period between July $15^{\text {th }}$ and October $13^{\text {th }}$. All employees were informed

129 about the objectives of the campaign and were invited to participate. No

130 clinical criteria were required to be tested. Tests were performed at the

131 different work sites by healthcare personnel according to the

132 manufacturers' instructions after a two-hours training session. For each

133 participant, a written informed consent was obtained. Test result was

134 provided within 15 minutes. A photograph of each cassette was 
medRxiv preprint doi: https://doi.org/10.1101/2021.01.27.21249186; this version posted January 29, 2021. The copyright holder for this preprint (which was not certified by peer review) is the author/funder, who has granted medRxiv a license to display the preprint in perpetuity.

It is made available under a CC-BY 4.0 International license .

135

136

137

138

139

140

141

142

143

144

145

146

147

148

150

151

152

153 154 line of the corresponding immobilized antibodies (anti-human IgM and/or 155 anti-human IgG), the complex is trapped and form a burgundy-colored band

systematically performed to be assessed by an independent operator. A standardized questionnaire was filled for each subject, including age, sex, working status and previous symptoms potentially related to a SARS-CoV-2 infection in the previous five months (i.e. fever, dyspnea, cough, flu-like syndrome, anosmia/ageusia).

\section{Point-of-care used test}

The COVID-PRESTO $®$ SARS-CoV-2 IgG/IgM antibody test kit is a lateral flow immune-chromatographic assay targeting antibodies specific to the SARS-CoV-2 N-protein. It has been manufactured and marketed by AAZLMB and already approved by French authorities. This rapid diagnostic test (RDT) uses anti-human IgM antibodies (test line IgM), anti-human IgG antibodies (test line IgG) and rabbit IgG (control line C) immobilized on a nitrocellulose strip. The Conjugate (recombinant SARS-CoV-2 antigens labeled with colloidal gold) is also integrated into the strip. When a specimen is well placed in the sample and the assay buffer is added, the IgM and IgG antibodies, if present, bind to the SARS-CoV-2 conjugates forming an antigen-antibodies complex. This complex migrates through a nitrocellulose membrane by capillary action. When the complex meets the 
medRxiv preprint doi: https://doi.org/10.1101/2021.01.27.21249186; this version posted January 29, 2021. The copyright holder for this preprint (which was not certified by peer review) is the author/funder, who has granted medRxiv a license to display the preprint in perpetuity.

It is made available under a CC-BY 4.0 International license .

156 confirming test result. Results must be read within 10 minutes by two

157 independent operators. When the control line is the only one present, the

sample is negative. If the control line does not appear, the test is invalid and

159 should be repeated with a new cassette. Performances of this test have

160 already been assessed in real life, regardless of the manufacturer's

161 instructions. The sensitivity of COVID-PRESTO® test ranged from 10\% for

162 patients having experienced their first symptoms from 0 to 5 days earlier to

$163100 \%$ in patients whose symptoms occurred more than 15 days earlier ${ }^{5}$.

Statistical analysis

166 Data were collected on an Excel spreadsheet. Data were categorized by

167 mine site, sex, age and working characteristics (i.e. direct employees vs

168 subcontractor's employees). Qualitative and quantitative variables

169 including the proportion of seropositivity were reported in percentage and

170 a 95\% confidence interval. Multivariate logistic regression was used to

171 determine the relationship between demographics characteristics and

172 seropositivity to the SARS-CoV-2. A p value of less than 0.05 was regarded

173 as statistically significant. Only statistically significant variables were

174 introduced in the multivariate model. Analysis was carried out using $\mathrm{R}$

175 studio software. 
medRxiv preprint doi: https://doi.org/10.1101/2021.01.27.21249186; this version posted January 29, 2021. The copyright holder for this preprint (which was not certified by peer review) is the author/funder, who has granted medRxiv a license to display the preprint in perpetuity.

It is made available under a CC-BY 4.0 International license.

177 Ethical considerations

178 The GISPE Research and Ethical committee approved the survey on May

$17915^{\text {th }} 2020\left(\mathrm{~N}^{\circ}\right.$ EC-GISPE014). Potential participants were informed about

180 the campaign purpose and procedures.

181

182 Results

183 Among the 3,380 employees, a total of 1,687 subjects (49.9\%) were

184 included in the study. One thousand five hundreds thirty-five were male

185 and 151 were female. Mean age was 37 (18-66) years old; 1,566 employees

186 (92.7\%) worked in the mine sites and 121 (7.3\%) in Abidjan. Among

187 mining workers, 845 were direct employees living night and day in the

188 compound (587 in mine $A$ and 258 in mine $B$ ), and 718 were

189 subcontractor's employees of other companies working in the mine during

190 the day but coming back to village after work (213 in mine A and 501 in

191 mine B). One thousand four hundreds fifty-eight workers were native from

192 Ivory Coast (86.4\%), 143 from another African country (8.5\%) and the

193 remaining 87 (5.1\%) came from 12 worldwide countries (Details in Table I)

194 Subjects working in Abidjan were significantly older (63\% over 36 years

195 old) and the proportion of male workers was half compared to mine sites.

196 Among the 1,687 people included in the study, 422 had a positive

197 serological test (either IgG and/or IgM). Overall seroprevalence was 25.1\% 
medRxiv preprint doi: https://doi.org/10.1101/2021.01.27.21249186; this version posted January 29, 2021. The copyright holder for this preprint (which was not certified by peer review) is the author/funder, who has granted medRxiv a license to display the preprint in perpetuity.

It is made available under a CC-BY 4.0 International license .

198 and prevalence rates were similar when stratified by age or gender.

199 According to the different working sites, the seroprevalence was $34.4 \%$,

$20034.7 \%$, and $13.6 \%$ in mine $A$, Abidjan headquarters and mine $B$.

201 Seroprevalence rate was significantly lower in subcontractors workers than

202 in those living full time in the mines. Ivory Coast natives had the highest

203 prevalence rate [26.5\% (24.3\% - 28.8\%)]. Conversely, people coming from

204 countries outside Africa were less likely to be SARS-CoV-2 seropositive

205 (Details in Table 2).

206 Among the 422 seropositive subjects, only one had previously been

207 hospitalized for a suspected COVID-19. Eighteen additional subjects had

208 mild symptoms and were diagnosed by a positive real-time reverse

209 transcription polymerase chain reaction (RT-PCR) test. Among the 404

210 remaining subjects, 74 reported mild nonspecific symptoms that may or

211 may not be attributable to a SARS-CoV-2 infection, particularly in a tropical

212 setting, but were not tested at the time of symptoms.

214 Discussion

215 The current epidemiological study conducted on a specific African

216 population reports a SARS-CoV-2 seroprevalence as high as 35\% in gold

217 mining workers as well as in administrative staff living in Abidjan. This

218 high seroprevalence rate has been reached before July 2020, and it 
medRxiv preprint doi: https://doi.org/10.1101/2021.01.27.21249186; this version posted January 29, 2021. The copyright holder for this preprint (which was not certified by peer review) is the author/funder, who has granted medRxiv a license to display the preprint in perpetuity.

It is made available under a CC-BY 4.0 International license .

219 remained stable after the first pandemic wave, between July and October

220 2020. This silent outbreak had not previously been detected because most

221 cases were asymptomatic.

222 From March to December 1st, 2020, Ivory Coast reported 21,250 SARS-CoV-

2232 infections and 127 COVID-19 related deaths, meaning that only the

$2240.084 \%$ of Ivory Coast's 25 million inhabitants has been infected ${ }^{2}$. Official

225 available data do not reflect the burden of infection but may reflect the

226 emerging part of the iceberg. To our knowledge, there are very few

227 published studies evaluating SARS-CoV-2 seroprevalence in African

228 countries. In Togo, among 955 participants from five different sectors, the

229 prevalence rate was $0.9 \%(95 \% \mathrm{CI}: 0.4 \%-1.8 \%)^{6}$. In a study conducted in

230 Kenya from April to June 2020 on 3,174 blood donors' samples,

231 seroprevalence was 5.2\% (95\%CI: 3.7\%-7.1\%)7. In two small populations

232 of household contacts and healthcare workers in Nigeria, seroprevalence

233 rates rise to $25.4 \%$ and $45 \%$ respectively ${ }^{8,9}$. Among the available pre-print

234 or published studies, seroprevalence was evaluated using Rapid Diagnostic

235 Tests (RDTs) in three studies, enzyme-linked immunosorbent assay (ELISA)

236 in three studies and Clinical Laboratory Improvement Amendments (CLIA)

237 in one study ${ }^{6-12}$. A recent study aiming to detect the persistence of SARS-

238 CoV-2 antibodies 3 to 4 months after the onset of symptoms in healthcare

239 workers at the Strasbourg University hospital reported that ELISA 
medRxiv preprint doi: https://doi.org/10.1101/2021.01.27.21249186; this version posted January 29, 2021. The copyright holder for this preprint (which was not certified by peer review) is the author/funder, who has granted medRxiv a license to display the preprint in perpetuity.

It is made available under a CC-BY 4.0 International license .

240 serological test has a 59\% sensitivity and Biosynex RDT a $85 \%$ sensitivity

241 compared to the S-flow reference test developed by the French National

242 Reference Center for SARS-CoV-2 infection (Pasteur Institute, Paris,

243 France ${ }^{13}$. The RDT used in our study showed high sensitivity even more

244 than 21 days after onset of symptoms, as well as a $100 \%$ specificity in a

245 study carried out independently from the manufacturer ${ }^{14}$. Hence,

246 seroprevalence rates from studies using ELISA tests must be cautiously

247 interpreted as they may underestimate the real data.

248 In our study, $14 \%$ to $35 \%$ of workers were SARS-CoV-2 seropositive,

249 despite having no symptoms or at least no severe disease. These data

250 appear to be quite different than that observed in the rest of the world, but

251 similar results have already been described in Ibadan, Nigeria, in healthcare

252 workers who are much more exposed to the infection than mine workers ${ }^{9}$.

253 A high level of seropositivity was found in both mining workers and

254 administrative staff living in the economic capital. In mine $A$, as people live

255 together, a cluster phenomenon may have occurred, explaining the

256 difference in seroprevalence with mine B, which was more confined during

257 the first wave with limited circulation between mine $B$ and Abidjan.

258 Subjects living in mine B had the same life habits as the African population

259 living in Abidjan. Therefore, we can expect that this similar seroprevalence

260 reflects the real one in Abidjan. 
medRxiv preprint doi: https://doi.org/10.1101/2021.01.27.21249186; this version posted January 29, 2021. The copyright holder for this preprint (which was not certified by peer review) is the author/funder, who has granted medRxiv a license to display the preprint in perpetuity.

It is made available under a CC-BY 4.0 International license .

261 In mine $\mathrm{B}$, subcontractors' workers constitute $67 \%$ of the working

262 population compared to $29 \%$ in mine A. As subcontractors' worker do not

263 live full-time in the mine, the lower seroprevalence of this population, could

264 reflect a lower prevalence in rural areas of the country.

265 In the capital, seropositivity was $34.7 \%$ among the 121 subjects working in

266 the administrative staff in Abidjan and having no contact with gold mines.

267 This data could reflect the high SARS-CoV-2 seroprevalence in the general

268 population living in Abidjan.

269 Nevertheless, the most surprising results of the current study are the

270 extremely low percentage of symptomatic cases and mortality rate. Some

271 authors speculate that African SARS-CoV-2 seroprevalence data could be

272 related to a younger population, a favorable climate and possible

273 preexisting immunity due to previous exposure to other coronaviruses ${ }^{14}$.

274 In our study, mean age was 37 years old and there was no increase in

275 symptoms incidence or hospitalization according to age range. Our

276 prevalence rates do not support hypothesis of a previous cross-reacting

277 immunity due to other coronaviruses.

278 Relatively stable prevalence rates observed between July and September

279 may indicate that SARS-CoV-2 outbreak occurred as early as March or April

280 as in Europe, mainly not to say exclusively from imported cases, and spread

281 silently but rapidly across the country. The plateau observed since July 
medRxiv preprint doi: https://doi.org/10.1101/2021.01.27.21249186; this version posted January 29, 2021. The copyright holder for this preprint (which was not certified by peer review) is the author/funder, who has granted medRxiv a license to display the preprint in perpetuity.

It is made available under a CC-BY 4.0 International license .

282 could be related either to complete travel restrictions, to the end of the first

283 epidemic wave as in Europe, to the nationwide control of the SARS-CoV-2

284 circulation, or may reflect other phenomena including pre-existing

285 immunity, genetic factors ... in the remaining population.

286

287 This study has some limitations. Firstly, the included population is not

288 representative of the general Ivoirian population, although subjects living

289 in Abidjan have similar habits to those of the Abidjan's population.

290 Furthermore, the voluntary test may have selected people thinking to be

291 more exposed to the virus, for example people who previously had mild

292 symptoms or had households contacts of a confirmed SARS-CoV-2 case.

293 Third, even if COVID-PRESTOß has an excellent diagnostic performance,

294 diagnostic sensitivity decreases a few months after the infection, compared

295 to the reference test S-Flow, and may therefore have underestimated the

296 real seroprevalence.

297

298 In conclusion, the high SARS-CoV-2 prevalence rate among mining workers

299 recruited for this study confirms a higher proportion of asymptomatic cases

300 than that observed in Europe, South America or United States of America

301 till now. Herd immunity could be achieved in Africa much easier than

302 expected without generating a dramatic health crisis. 
304 *: Corresponding author: Thierry Prazuck, Service des maladies infectieuses

305 et tropicales, Centre Hospitalier Regional d'Orleans, 14 avenue de l'hopital,

30645067 Orleans, Cedex 2, France . thierry.prazuck@chr-orleans.fr, phone:

$307 \quad 00(33) 238229593$

308

309

310 References:

311 1. WHO Coronavirus Disease (COVID-19) Dashboard [Internet]. [cité 17

312 déc 2020]. Disponible sur: https://covid19.who.int/table

313 2. COVID-19 Situation update for the WHO African Region, External

314 Situation Report 34 (21 October 2020) - South Africa [Internet].

315 ReliefWeb. [cité 17 déc 2020]. Available at:

316 https://apps.who.int/iris/bitstream/handle/10665/336181/SITREP_C

317 OVID-19_WHOAFRO_20201021-eng.pdf

318 3. Payne C. COVID-19 in Africa. Nat Hum Behav. mai 2020;4(5):436-7.

4. Myers J. MAVERICK CITIZEN OP-ED: Covid-19: After a severe epidemic,

320 South Africa appears to be approaching some herd immunity [Internet]. 
medRxiv preprint doi: https://doi.org/10.1101/2021.01.27.21249186; this version posted January 29, 2021. The copyright holder for this preprint (which was not certified by peer review) is the author/funder, who has granted medRxiv a license to display the preprint in perpetuity.

It is made available under a CC-BY 4.0 International license .

322 https://www.dailymaverick.co.za/article/2020-10-07-covid-19-after-

323 a-severe-epidemic-south-africa-appears-to-be-approaching-some-

324 herd-immunity/

325 5. Prazuck T, Colin M, Giachè S, Gubavu C, Seve A, Rzepecki V, et al.

326 Evaluation of performance of two SARS-CoV-2 Rapid IgM-IgG combined

327 antibody tests on capillary whole blood samples from the fingertip.

$328 \quad$ PLoS One. 2020;15(9):e0237694.

329

330

331

332

333

334

335

336

337

338

339

340

6. Halatoko WA, Konu YR, Gbeasor-Komlanvi FA, Sadio AJ, Tchankoni MK, Komlanvi KS, et al. Prevalence of SARS-CoV-2 among high-risk populations in Lomé (Togo) in 2020. PLoS One. 2020;15(11):e0242124.

7. Uyoga S, Adetifa IMO, Karanja HK, Nyagwange J, Tuju J, Wanjiku P, et al. Seroprevalence of anti-SARS-CoV-2 IgG antibodies in Kenyan blood donors. medRxiv. 29 juill 2020;2020.07.27.20162693.

8. Asuquo MI, Effa E, Otu A, Ita O, Udoh U, Umoh V, et al. Prevalence of IgG and IgM antibodies to SARS-CoV-2 among clinic staff and patients. medRxiv. 24 juill 2020;2020.07.02.20145441.

9. Olayanju 0, Bamidele O, Edem F, Eseile B, Amoo A, Nwaokenye J, et al. SARS-CoV-2 Seropositivity in Asymptomatic Frontline Health Workers in Ibadan, Nigeria. Am J Trop Med Hyg. 11 nov 2020; 
medRxiv preprint doi: https://doi.org/10.1101/2021.01.27.21249186; this version posted January 29, 2021. The copyright holder for this preprint (which was not certified by peer review) is the author/funder, who has granted medRxiv a license to display the preprint in perpetuity.

It is made available under a CC-BY 4.0 International license.

341 10. Majiya H, Aliyu-Paiko M, Balogu VT, Musa DA, Salihu IM, Kawu AA, et al.

342 Seroprevalence of COVID-19 in Niger State. medRxiv. 5 août

$2020 ; 2020.08 .04 .20168112$.

344

345

346

347

348

350

351

352

359

360

361

11. Kempen JH, Abashawl A, Suga HK, Nigussie Difabachew M, Kempen CJ, Tesfaye Debele M, et al. SARS-CoV-2 Serosurvey in Addis Ababa, Ethiopia. Am J Trop Med Hyg. nov 2020;103(5):2022-3.

12. Chibwana MG, Jere KC, Kamng'ona R, Mandolo J, Katunga-Phiri V, Tembo D, et al. High SARS-CoV-2 seroprevalence in Health Care Workers but relatively low numbers of deaths in urban Malawi. medRxiv. 1 août 2020;

13. Grzelak L, Velay A, Madec Y, Gallais F, Staropoli I, Schmidt-Mutter C, et al. Sex differences in the decline of neutralizing antibodies to SARSCoV-2. medRxiv. 15 nov 2020;2020.11.12.20230466.

14. Njenga MK, Dawa J, Nanyingi M, Gachohi J, Ngere I, Letko M, et al. Why is There Low Morbidity and Mortality of COVID-19 in Africa? Am J Trop Med Hyg. ao2020;103(2):564-9. 


\begin{tabular}{|c|c|c|c|c|c|}
\hline Characteristics & Overall & Ity & Agbaou & Abidjan & $\mathrm{p}$ \\
\hline $\mathrm{N}$ & 1687 & 803 & 763 & 121 & \\
\hline Sex ratio $(M / F)$ & 10.2 & 14.1 & 10.1 & 3.17 & $<0.001$ \\
\hline $\begin{array}{l}\text { Age } \\
\text { Mean (SD) } \\
\qquad \begin{aligned} \text { - } & <36 \\
\text { - } & 36-49 \\
\text { - } & >=50\end{aligned}\end{array}$ & $\begin{array}{l}38(8.6) \\
805 \\
733 \\
149\end{array}$ & $\begin{array}{l}36(8.3) \\
400 \\
338 \\
65\end{array}$ & $\begin{array}{l}37(8.7) \\
359 \\
336 \\
68\end{array}$ & $\begin{array}{l}39(9.7) \\
46 \\
59 \\
16\end{array}$ & $\begin{array}{l}0.001 \\
\text { NS }\end{array}$ \\
\hline $\begin{array}{l}\text { Employee's status } \\
\text { - Direct employees } \\
\text { - Subcontractors } \\
\text { - Administrative } \\
\text { staff }\end{array}$ & $\begin{array}{l}848 \\
721 \\
118\end{array}$ & $\begin{array}{l}587 \\
213 \\
3\end{array}$ & $\begin{array}{l}258 \\
505\end{array}$ & $\begin{array}{l}3 \\
3 \\
115\end{array}$ & $<0.001$ \\
\hline
\end{tabular}

\begin{tabular}{|c|c|c|c|c|c|c|}
\hline & & Univariate & & & Multivariate & \\
\hline & $\mathrm{N}$ & $\begin{array}{c}\text { Prevalence } \\
{[95 \% \mathrm{CI}]}\end{array}$ & OR & $\mathrm{P}$ & $\begin{array}{c}\mathrm{aOR} \\
(95 \% \mathrm{CI})\end{array}$ & $\mathrm{P}$ \\
\hline $\begin{array}{r}\text { Gender } \\
\text { Female } \\
\text { Male }\end{array}$ & $\begin{array}{l}151 \\
1536\end{array}$ & $\begin{array}{l}25,2 \%[18,2 \%-32,1 \%] \\
25 \%[22,8 \%-27,2 \%]\end{array}$ & $\begin{array}{l}1,01[0,94-1,09] \\
0,99[0,92-1,07]\end{array}$ & NS & $\begin{array}{l}0,88[0,58-1,3] \\
1\end{array}$ & NS \\
\hline
\end{tabular}


medRxiv preprint doi: https://doi.org/10.1101/2021.01.27.21249186; this version posted January 29, 2021. The copyright holder for this preprint (which was not certified by peer review) is the author/funder, who has granted medRxiv a license to display the preprint in perpetuity.

It is made available under a CC-BY 4.0 International license .

380

381

382

383

384

385

386

387

388

389

390

\begin{tabular}{|c|c|c|c|c|c|c|}
\hline $\begin{array}{r}\leq 35 \\
36-49 \\
\geq 50\end{array}$ & $\begin{array}{l}805 \\
733 \\
149\end{array}$ & $\begin{array}{l}24,8 \%[21,9 \%-27,8 \%] \\
25,2 \%[22,1 \%-28,4 \%] \\
24,8 \%[17,9 \%-31,8 \%]\end{array}$ & $\begin{array}{l}0,98[0,96-1,01] \\
1,02[1-1,05] \\
0,99[0,92-1,07]\end{array}$ & NS & $\begin{array}{l}1 \\
1,04[0,82-1,33] \\
1,18[0,75-1,82]\end{array}$ & $\begin{array}{l}\text { NS } \\
\text { NS }\end{array}$ \\
\hline $\begin{array}{l}\text { Employees status } \\
\text { Direct emplyees } \\
\text { Subcontractors } \\
\text { Administrative } \\
\text { staff }\end{array}$ & $\begin{array}{l}848 \\
721 \\
118\end{array}$ & $\begin{array}{l}33,3 \%[30,1 \%-36,4 \%] \\
13,7 \%[11,2 \%-16,2 \%] \\
34,7 \%[26,2 \%-43,3 \%]\end{array}$ & $\begin{array}{c}2,49[2,4-2,56] \\
0,32[0,3-0,33] \\
1,66[1,53-1,8]\end{array}$ & $\begin{array}{c}<0.001 \\
* * *\end{array}$ & $\begin{array}{l}2,33[1,8-3,1] \\
1 \\
1,58[0,34-6,8]\end{array}$ & $\begin{array}{c}0.001 * * \\
\text { NS }\end{array}$ \\
\hline $\begin{array}{r}\text { Country of origin } \\
\text { Ivory Coast } \\
\text { African other } \\
\text { Non-African }\end{array}$ & $\begin{array}{l}1458 \\
143 \\
86\end{array}$ & $\begin{array}{l}26,5 \%[24,3 \%-28,8 \%] \\
16,1 \%[10,1 \%-22,1 \%] \\
14 \%[6,6 \%-21,3 \%]\end{array}$ & $\begin{array}{l}2[1,86-2,15] \\
0,55[0,5-0,6] \\
0,47[0,4-0,57]\end{array}$ & $\begin{array}{c}0.001 \\
* *\end{array}$ & $\begin{array}{l}3.5[1,9-7] \\
1,8[0,9-4.2] \\
1\end{array}$ & $\begin{array}{c}0.001^{*} \\
\mathrm{NS}\end{array}$ \\
\hline $\begin{array}{l}\text { Location } \\
\qquad \begin{array}{r}\text { Mine A } \\
\text { Mine B } \\
\text { Abidjan }\end{array}\end{array}$ & $\begin{array}{l}803 \\
763 \\
121\end{array}$ & $\begin{array}{l}34,4 \%[31,1 \%-37,7 \%] \\
13,6 \%[11,2 \%-16,1 \%] \\
34,7 \%[26,2 \%-43,2 \%]\end{array}$ & $\begin{array}{l}2,65[2,58-2,72] \\
0,3[0,3-0,3] \\
1,66[1,53-1,8]\end{array}$ & $\begin{array}{c}<0.001 \\
* * *\end{array}$ & $\begin{array}{l}2,54[1,9-3,35] \\
1 \\
3,5[0,8-16,4]\end{array}$ & $\begin{array}{c}<0.001 * * * \\
\mathrm{NS}\end{array}$ \\
\hline
\end{tabular}

Table II: SarS-CoV2 seroprevalence rates, odds ratios and 95\% confidence interval according to sociodemographic characteristics plus adjusted odds ratio (logistic model). 